\title{
Experiences From Virtual Learning in Upper Secondary Schools in Finland
}

\author{
Jari Koivisto \\ Finnish National Board of Education \\ P.O. Box 380, FIN-00531 Helsinki Finland \\ jari.koivisto@oph.fi \\ www.oph.fi
}

\begin{abstract}
In every country there has been a lot of worry and discussions how to make sure that the schoolchildren and the student can acquire sufficient skills and efficacy in using computers to be more efficient and productive in their studies and later in their professional career. One of the answers to this challenge in Finland has been the National Information Society Programme supporting the procurement of computers, building computer networks, training teachers and creating methods of teaching in a computer intensive environment. The programme has been running for ten years now, and there are a wide range of experiences from failures to brilliant successes. The most important lesson learned is that the technical networking, mental networking and organizational networking should take place simultaneously as well as the teacher understanding about the special role of ICT in education.
\end{abstract}

\section{The Information Society Programme}

The strategic importance of ICT in business and in education has been growing fast during the previous two decades. This process led to the idea to have a national programme advancing the use of ICT much more effectively in education. As a consequence the Finnish Information Society programme was launched in 1996 and since then the Finnish government has provided noticeable funding to the Finnish educational institutes, including the general education schools, to make ICT an effective tool in education. The programme is comprised of several subprogrammes during three strategy periods focusing on various goals. The latest strategy period covers the years 2004 through 2006 [1]. 
The main goal of the national information society strategies has been to support a well balanced development of the use of ICT in all levels of education and in all the factors contributing to its success. Therefore there have been four subprogrammes ,each supporting its equally important factor of development.

The main parts of the programme have been

- Pedagogical ICT training for the teachers

- ICT intensive teaching methods development

- Computers for the schools

- Network connections for the schools

It is interesting to see that the two pedagogically-oriented subprogrammes first on the list go hand in hand with the technical development programmes. This means that the ministry has understood that all pedagogical development in using ICT in education requires proper technical facilities. What is missing are the technical and pedagogical support to use ICT in a regular classroom situation at schools and the learning material. The ICT support for the schools is a serious challenge because the municipalities and cities are reluctant to provide funding for that purpose. The availability of learning material is, however, reasonable because there are a number of initiatives in several organizations and among book publishers to create digital learning material to schools. Resources are available from several sources.

One of the main ideas in the theoretical background of the information society processes is the importance of the student's own initiative in the learning process. The students should develop their ideas by their own thinking, testing their mental structures and conceptions of reality and creating at the same time a correct mental construction of the reality. Learning cannot be effective without the student actively conducting studies [2]. Teaching might be important in a classroom but learning is the core activity in education. The ICT is considered an important tool for moving the emphasis in the classroom situation from teaching to studying, practicing and learning. The Internet provides a huge source of facts and learning material, but the teachers are hesitating to use the Internet because of the abundance of incorrect material that might confuse the students.

\section{Technology}

The question of the penetration of technology to school is important. Many times the focus in developing the school is on the pedagogy and teaching methods. It is, however, obvious that only in a highly computer-intensive environment can the technology move to the background processes adopting a real role as a tool. I consider a learning environment to be ICT-intensive if there are fewer than 3 students per one computer which is connected to the Internet and available for the students.

The technology is advancing very fast, creating new possibilities for the schools such as intelligent black boards or white boards, wireless communication, mobile TV, virtual presence, virtual classes, etc. However, the schools are quite sparsely funded everywhere in the world and it is highly improbable that schools will be the first to adopt new technologies. This is the case also in Finland, but it can also be a 
relief to the teachers to have a bit slower pace. The teachers normally familiarize themselves with new technologies during the regular annual in-service training.

The high ICT penetration in the schools opens new possibilities to organise tests, exams and many kinds of performance evaluations using the computers provided by the schools, but it is possible also to use the students' own laptop computers or computers from some other sources. In every case the schools have to make sure that cheating is made difficult and the penalty for cheating is high. Denmark has a lot of experience in organizing exams where the students are allowed to use computers. In those cases it is always advisable to let the students use any additional material they might want, but not the Internet, because when using the Internet it is not certain who is the real author of the given answers in the exam.

\section{The virtual school networks}

At the moment the focus in the virtual school is on the school networks using ICT to share the expertise and resources in producing high quality educational services. The studies in the upper secondary schools in Finland are based solely on passing one or several courses in each subject. The length of each course is 38 lesson hours. The whole upper secondary school curriculum is comprised of 75 courses with 45 mandatory and 30 optional courses, and a national final exam. Normally there is quite a large collection of optional courses available for students in each of the schools. To produce all these courses for students is a heavy economical burden for the school. Therefore schools have found it more economically feasible to organize this large variety of courses together with other schools using ICT.

The precondition for this kind of cooperation is the availability of computers and networks in the school. There should also be special rooms available for those groups of students using virtual methods while studying their courses. One of the most popular methods at the moment is to create a virtual learning group connecting smaller groups from many schools. This virtual group is using videoconferencing to communicate, and the teacher can be in any of the schools. There might also be several teachers or no teacher at all in the videoconferencing session, or the teacher can participate in a very flexible way. In almost all the cases that I know there is one teacher present all the time.

For an average teacher to become a virtual teacher, being comfortable with all the technology, it seems to require qualified teachers with reasonable experience in using computers and networks, a short training in using videoconferencing technically, a longer training to use videoconferencing in a pedagogically meaningful way, and about three year's time working as a virtual teacher. Of course after three years of virtual teaching the teacher is equally comfortable with the Internet, email, the learning platforms and many other possibilities provided by ICT.

The learning results when using the virtual methods seem to be comparable with the learning using conventional methods. Of course, it is relatively difficult to collect reliable statistical data because normally there is no test group of students available. The students are normally much more comfortable with the new methods, and there are only a very few complaints. The general atmosphere in a school seems to be improving, and the cooperation between the teachers is increasing, if the school 
is actively pursuing a new attitude in education. The school leadership is important, and the school leader is wise to encourage teachers' own initiative and support the growth of each individual teacher's expertise and empowerment [3]. Sometimes socalled strong leadership in the school can cause a lot of damage when blocking the empowerment process in the school and preventing the teachers' professional growth.

\section{The challenges}

Generally the Finnish schools are quite small, resulting in high expenses when making sure that all the subjects are taught according to the requirements of the national curriculum, and that all the teachers in every subject are fully qualified. Therefore the schools are continuously pursuing new ways of providing high quality education with fewer expenses. The virtual teaching methods might be at least a partial solution.

The fast development of the social and economical situation in the country induces special requirements to the quality of education. The contents of the learning materials should be updated fast, the in-service training of the teachers should be continuous, and new developments in the society should filter without delay to the school. When the school students leave their school they should be fully prepared to meet the challenges of society.

A special challenge in Finland, compared with almost all the other European countries, are the vast sparsely-populated areas where the schools are small, expenses high and the difficulties in providing the families with high quality educational services are severe. These challenges are continuously increasing because of the internal migration from rural areas to urban areas.

\section{General}

The Finnish Information Society Programme has meant a huge leap in the development of ICT-intensive teaching and learning environments for the Finnish schools. Almost all the schools are connected to the Internet by fast connections, the computers are available in the Finnish schools in big numbers, the teachers are trained to use the computers and the Internet in their lessons in a pedagogically meaningful way, and the students can use the computers and networks for their studies both in school and at home.

The schools and the teacher have adopted a number of new methods in working in a computer-intensive educational environment, and the students are learning many of those skills needed in the future when the work places, tasks and the working environment are genuinely different from what they are now. I think that this is the only acceptable way to develop education. 


\section{References}

1. The Finnish Ministry of Education, 2004. Information Society Programme for Education, Training and Research 2004-2006, Referred April 7, 2006

http://www.minedu.fi/julkaisut/koulutus/2004/opm14/opm14.pdf.

2. Uljens, M. 1997. School didactics and learning. Hove: Psychology Press.

3. Nokelainen, P., \& Ruohotie, P, 2003. Common Components Between Dimensions of Growth-oriented Atmosphere and Empowerment. In Proceedings of International Research on Work and Learning (RWL) Conference, pp. 176-185. Tampere, Finland. 